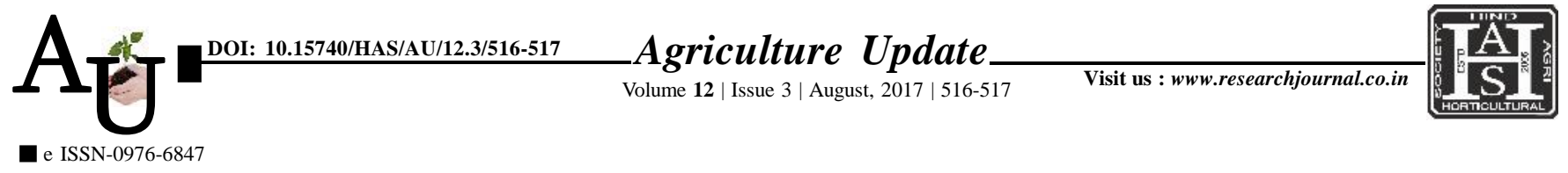

\title{
Research Note: Constraints faced by green house adopters in zone 1 b of Rajasthan
}

D.S. BHATI

Article Chronicle : Received :

17.05.2017;

Accepted :

29.07.2017

KEY WoRDS:

Green house, Climatic factors

Author for correspondence :

\section{D.S. BHATI}

Krishi Vigyan Kendra, AJMER (RAJASTHAN)

INDIA

Email:dsbhati06@rediffmail. com

How to cite this article : Bhati, D.S. (2017). Constraints faced by green house adopters in zone $1 \mathrm{~b}$ of Rajasthan. Agric. Update, 12(3): 516-517; DOI : 10.15740/HAS/AU/12.3/516-517.

Green house means polythene film covered house in which climatic factors controlled for cultivation of crops. Green house having close structure so that stored carbon dioxide of it utilized by plant itself for food preparation and for plant growth. Crops grown in the green house under controlled condition, so yield is higher.

Type of green house changes from place to place and it is depending upon topography. For covering green house various types of poythene used. In north Rajasthan 200 micron usually used. In Sriganganagar and Hanumangargh districts farmers already adopted green house but they are facing some constraints with new technology adoption. Present study was conducted to know the constraints faced by them with the following specific objectives:

- To identify the constraints faced by green house adopters.

- To study type and structure of green house adopted by the farmers.

The study was conduced in Sriganganagar and Hanumangarh districts. The list of green house adopters was obtained from agriculture and horticulture. In all 50 green house adopters were selected. Purposive sampling was done. The schedule was designed. The green house adopters were interviewed with the help of structured interviewed schedule personally. The data were presented through primary and secondary tables. The data were analyzed. The frequenting and percentage were used for presenting the data.

Table 1 revealed that out of 50 respondent, majority of the respondents $(60.00 \%)$ facing the problem of lack of technical knowledge. These finding are in line with Singh et al. (1998) and availability of soil analysis report.

It is observed that 56.0 per cent respondents getting expected rate and rest $(44.00 \%)$ of respondents not satisfied with the rate. It is revealed that majority of green house adopters $(44.00 \%)$ face the problem of middle men which one giving own rates. The findings are in line with findings of Shaikh et al. (1993) and Singh et al. (1998). The 40.00 per cent respondents reported that they are not getting technical knowledge in time.

It is revealed from Table 2 that 70.0 per cent respondents having GH-1 type green 